\title{
Interaction between Voluntary and Statutory Social Service Provision in Sweden: A Matter of Welfare Pluralism, Substitution or Complementarity?
}

\author{
Lena Dahlberg
}

\begin{abstract}
Many welfare states have met with criticism and it has been argued that they are in crisis. Simultaneously, there has been a greater openness to voluntary work as an alternative to statutory services, for example in Sweden. Sometimes the activities of voluntary organizations have been seen as complementary to those of local authorities; at other times this issue has been addressed in terms of welfare pluralism. However, countries with strong welfare states have often been assumed to have insignificant voluntary work - as claimed in substitution theory. The purpose of this article is to examine variation in welfare service provision in the light of welfare pluralism, substitution theory and complementarity theory. The study was carried out in the area of support for relatives of older people in Sweden. It was conducted by means of national questionnaire surveys of voluntary organizations and local authorities in 1999 and 2002. In this period, there was an increase in statutory service provision and more voluntary organizations were involved in service provision. However, it is yet too early to describe this in terms of welfare pluralism. Neither was any evidence found for substitution theory. Furthermore, overlaps in service provision from voluntary organizations and local authorities question complementarity theory, which assumes that different actors specialize in different tasks. Nevertheless, the actors tended to be complementary at a local level. It is suggested that this complementarity might be explained by ideological support for a norm of complementarity.
\end{abstract}

\section{Keywords}

Welfare pluralism; Substitution; Complementarity; Voluntary organization; Welfare state; Informal care; Older people; Sweden

\section{Introduction: Shifting Roles of Welfare Providers}

Over recent decades, many welfare states have been severely criticized. The Swedish welfare state has often been regarded as a model for welfare states.

Address for correspondence: Lena Dahlberg, Centre for Research and Evaluation, Sheffield Hallam University, City Campus, Howard Street, Church House, Sheffield, SI IWB. Email: L.Dahlberg@shu.ac.uk 
For example, Esping-Andersen (1994) has noted that what make the Swedish welfare state unique are the universal welfare, the level of equality, the strength of social rights, and the efficiency of the system. Other researchers have pointed out the mutual agreements in the labour market, the system of corporatism, the goal of full employment, the promotion of equal opportunities for men and women, and a high level of mutual understanding/trust (see e.g. Premfors 1999; Rothstein I998; Vogel 1999). However, the Swedish welfare state has also met with criticism - for instance in the Swedish media, where it has been argued that Sweden can hardly be characterized as a welfare state (Södersten 2002), that the Swedish model is in its "death-throes" (Kjöller 2002; my translation) and so on.

With the ambition of reconstructing welfare states and with inspiration from the United States, New Public Management (NPM) ideas were discussed and to some extent tested in countries like the United Kingdom and Sweden in the I980s, and established in the early I99os (see e.g. Langan 2000; Montin 1997; Trydegård 2001; Wollmann 2004). In NPM, market-oriented principles are transferred to and applied by the public sector in order to overcome welfare state failures (Wollmann 2004). NPM includes privatization, outsourcing and marketization, i.e. cutbacks of the public sector. It also includes private sector managerialism, that is, introducing managerialist principles such as performance goals (Wollmann 2004).

In the United Kingdom, these ideas were discussed in terms of the Third Way - described in most detail by Giddens (1999) and in practice strongly promoted by the prime minister, Tony Blair. Although the Third Way was originally meant for the United Kingdom, it has met with sympathy elsewhere in Europe (Esping-Andersen 2002). It relates to the renewal of social democracy, in which the term "welfare state" is replaced by "welfare society" and in which, for example, voluntary organizations are expected to have a more active role in the provision of welfare services. In Sweden, NPM meant that market ideas and managerialism were applied within local authoritieswith a purchaser/provider split, competing units of providers, performance goals, etc.- - and that some public services were privatized. It also meant that local authorities embarked upon outsourcing the provision of services. Thereby, the local authorities were up against competition from private/ commercial providers and sometimes also from voluntary organizations, particularly regarding care for older people (Montin i997; Wollmann 2004).

Parallel with greater openness for private alternatives to public services, expectations increased for voluntary organizations to contribute to solutions of welfare state problems. Both the Swedish government and the EU promote partnership between the state/local authorities and voluntary organizations (see e.g. Larsson 2002; Socialstyrelsen 2003), including collaboration in specific areas such as support for relatives of older people (Proposition I997/98: II3).

It is believed that voluntary activity can relieve the pressure on public expenditures. Voluntary organizations are also seen as resources in relation to political crisis where the legitimacy of the welfare state is under debate. Then it is claimed that the welfare state, through its top-down distribution of support and privileges, is not democratic, that it limits individual freedom, 
and that it is bureaucratic and inefficient (see Henriksen i996). Voluntary organizations are assumed to support participation in local decision-making processes and also improve the connections between local needs and political priorities. At a rhetorical-ideological level, it has also been argued that the welfare state undermines individual initiative, breaks down the capacity of informal networks, and creates a dependency culture (see Kuhnle and Alestalo 2000). Here, voluntary organizations are seen as a mediating structure between citizens and the state.

\section{Theoretical Framework}

Increased expectations of voluntary organizations and their relationship to statutory service provision have been discussed in terms of welfare pluralism. They have also been considered within substitution theory and complementarity theory. There are thus three competing theories. The purpose of this article is to examine the variation in welfare service provision by voluntary organizations and local authorities in the light of these theories.

Ideas of welfare pluralism, substitution and complementarity originally derived from political contexts and they have often been used for ideological purposes. When transferred into research, they have remained relatively vaguely defined. In this section, some background will be given to the welfare pluralism approach, substitution theory and complementarity theory, and some testable premises will be identified. However, first a few remarks will be made on the concept of "voluntary organization".

\section{Remarks on the concept of "voluntary organization"}

Organizations studied in this article are in research and practice variously called voluntary organizations, non-profit organizations, non-governmental organizations, non-market organizations, collective organizations, charitable organizations, philanthropic organizations, grassroots organizations, social movement organizations, interest organizations, popular movement organizations, etc. These are part of what is sometimes called the civil society or social economy, and sometimes the independent sector, the voluntary sector, the third sector, etc.

Although these terms define roughly the same phenomenon, they emphasize different characteristics, are part of different discourses and have different normative connotations. These organizations are characterized by being established on the basis of common ideas or the interests of their members, and being built on voluntary and personal membership (Blennberger i993; Henriksen I996). Furthermore, these organizations are, in principle, neither owned by the state nor part of the commercial, for-profit market, that is, they are both non-governmental and non-profit. However, in practice such distinctions can be somewhat blurred. For instance, voluntary organizations and statutory bodies such as local authorities are influenced by and acquire characteristics from one another. Accordingly there are sometimes more similarities between voluntary and statutory organizations in the same fieldsuch as culture, social work, sports, etc.- than between voluntary organizations 
in different fields (see e.g. Pestoff i992; Selle and Øymyr 1995). Furthermore, there are financial links between voluntary organizations on the one hand and local authorities and the central state on the other, where voluntary organizations are paid to provide certain services or receive subsidies from local authorities and/or the central state (Johansson 20or; Kuhnle and Selle i992).

In this article, the term "voluntary organizations" is used. This term accentuates the voluntary (social) work and is part of a British tradition, although nowadays it is also frequently used in Swedish discourse. The word "voluntary" places focus on the relation between private and public (Lorentzen 1998), and is often used in order to differentiate between services provided by these organizations and services provided by statutory bodies (see e.g. Blennberger I993). In this article, the choice of the term "voluntary organization" is thus motivated by the fact that the study presented here highlights service production and the role of organizations in a welfare state context.

It is important to note, though, that the use of the term has been criticized since there is a risk of overlooking the fact that a lot of people are employed by these organizations and their work is scarcely voluntary in the unpaid meaning of the term (see Lorentzen 1998; Wijkström and Lundström 2002). In this article, no differentiation is made between paid and unpaid services provided by voluntary organizations or whether these services are funded or subsidized by the welfare state. Instead, focus is placed on which actor is providing certain services.

\section{Welfare pluralism}

Of the three theories studied in this article, the welfare pluralism approach is the vaguest and, although this approach is frequently referred to both in political debate and in research, its underlying assumptions have rarely been tested. While Johnson (1987) has claimed that the term lacks precision, Kramer (1992) has argued that the concept of welfare pluralism is merely a metaphor and not a model or a theory that can describe or explain the process of interpenetration of the state by the market and the voluntary sector.

The approach of welfare pluralism focuses on the fact that a variety of actors can deliver welfare services - or in the words of Hatch and Mocroft (1983: 2): "welfare pluralism can be used to convey the fact that social and health care can be obtained from four different sectors - the statutory, the voluntary, the commercial and the informal". A transition towards welfare pluralism is signified by a purposive duplication of activity by different actors. Users are thereby offered a choice between alternative services in a pluralized market of services, and accordingly the approach of welfare pluralism is often linked to decentralization and participation (Barnes and Walker I996; Hatch and Mocroft I983; Johnson I987; Walker i989). In this respect, the welfare pluralism approach fits well with policies of community care, especially when this is interpreted as care by, rather than in, the community (Johnson 1987; Walker I989). Furthermore, Powell and Hewitt 
(I998: 4) have argued that the (British) public welfare system was designed to deliver a universal "national minimum" and that "above this minimum, individuals were meant to increase their welfare by means of voluntary insurance leading to a mixed economy of voluntary, private and state welfare".

Sometimes, welfare pluralism has been discussed in terms of "welfare mix" or "mixed economy of welfare". These terms are often used in comparisons between different countries and welfare states. For example, Vogel (I999: 247) has defined welfare mix as "the configuration of welfare delivery systems, i.e. the market, welfare state and the family". Similarly, Powell and Barrientos (2004: 86) have discussed welfare mix as "the articulation of the markets, the state and the family in welfare production", and Esping-Anderson has emphasized that welfare regimes must be identified in terms of the "triad of state, market and family" (quoted in Powell and Barrientos 2004: 86). It should be noted that, as above, the contributions of voluntary organizations are often overlooked in welfare state research (cf. Graefe 2004). Nevertheless, Johnson (I987) has argued that the term "welfare pluralism" was initially used in the discussion of a reappraisal of the voluntary sector.

The welfare mix/welfare pluralism approach is linked to NPM ideas as presented above in the introduction. Welfare pluralism can be seen as a way of maintaining or supporting a pluralistic system, but also as a way of, at least in part, replacing the state as a service provider (Hatch and Mocroft I983; Johnson I987; Walker ig89). It has been suggested that there is a competitive relationship between the different actors (see e.g. Blennberger I993; Forder et al. i996). However, welfare pluralism does not necessarily have to be characterized by competition, since voluntary services might be "contracted out" and even coordinated by the state. Nevertheless, it can be argued that "social care markets" are at the core of the mixed economy of welfare (Forder et al. I996: 202).

Finally, it should be noted that interpretations of welfare pluralism are far from neutral. To put it simply: while the right may see welfare pluralism as a way of reducing the role of the welfare state and transferring statutory services to the private market, the left welcomes a more participatory and less bureaucratic welfare provision (Johnson ig87).

\section{Substitution theory}

In research on welfare regimes, social democratic regimes such as Sweden are assumed to constrain the conditions of other actors, such as private companies and voluntary organizations (see for example Anheier and Salamon 200I; Esping-Andersen I990). Then the underlying assumption is that extensive welfare states crowd out (private and) voluntary work. In Sweden, it has been argued that the state has "invaded" civil society, and that "state forces have claimed the civil society responsibility for care" (Zetterberg I995: 79, 8I; my translation). As a consequence, informal social networks are weakened, and solidarity is undermined (see Kuhnle and Alestalo 2000; Rothstein 2002).

This conclusion is drawn in relation to the role of the family as well as the role of voluntary organizations. In fact, it has been questioned whether 
Sweden has a voluntary sector at all (Boli i99I). In line with this, James (I989: 53, 39) has argued that Swedish voluntary organizations "play only a small role ... as a producer of quasi-public services" and her findings are "roughly consistent with a model in which voluntary contributions diminish (are 'crowded out') as government spending on public goods increases".

This argument has been promoted within substitution theory (in economic research this has been discussed in terms of "crowding out"; see e.g. Andreoni I993; Brunner 1997; Steinberg 1987; see also Künemund and Rein 1999). Substitution theory implies an inverse relationship between statutory and voluntary services, where increased statutory services are assumed to lead to a decrease in voluntary services, and vice versa. The interaction between statutory and voluntary organizations is often illustrated by the relation between two corresponding vessels or by a zero-sum-game (Blennberger 1993; see also Giddens 1999).

The logical rationale of the zero-sum game assumption in substitution theory has been criticized. For example, Kuhnle and Selle (I992: I4) have concluded that "it is not logically impossible to have a strong and active welfare state and voluntary organizations which simultaneously play important roles". It has also been questioned - for example by promoters of complementarity theory and welfare pluralism (Johnson I990; Litwak I985; see also Esping-Andersen 2002) - whether different actors, such as voluntary organizations and local authorities, are able to substitute for one another at all.

Ideologically, Rothstein (2002: 3I3) has pointed out that there are arguments from the political right as well as the political left that there is an inverse relationship between the state and civil society (see also Stolle and Rochon I999). The right claims, according to Rothstein, that people will stop caring when altruism and social problems are taken over by the government. Informal social networks will be weakened and support for those in need will be shown only through the payment of taxes. Concerning the argument from the left, Rothstein has referred to Habermas's statement that the welfare state has "colonized" civil society and that it undermines the "natural" forms of solidarity. Finally, Rothstein has noted that it is somewhat peculiar that these arguments are hardly ever substantiated by empirical evidence.

\section{Complementarity theory}

Complementarity theory has been presented in most detail by Litwak (1985), who has claimed that each organization or group has specific characteristics, which make it suitable to carry out certain tasks. He has stated that " $A$ group can optimally manage those tasks that match it in structure" (I985: 28; italics in original); this is also labelled the "principle of matching" (I985: 27). This theory has been discussed as well in terms of "specialization theory" (Lingsom I997; Daatland and Herlofsson 200I) and the "task-specific model" (Lyons et al. 2000), where different actors are seen as providing different kinds of services (Daatland and Herlofsson 200i).

Formal, statutory organizations are most appropriate to complete uniform tasks that benefit from task simplification through division of labour (Litwak 
I985). Specialized tasks that require skill and can occur at fixed times tend to be carried out by formal caregivers/statutory organizations (Lyons et al. 2000). By comparison, Litwak has argued that members of voluntary organizations are motivated by altruistic incentives and have very limited time commitments. These commitments are secondary to their family and occupational commitments. As a result, volunteers cannot guarantee that they will fulfil a service over a long period or for any given week, even though they can provide several hours of voluntary work per week. This implies that volunteers are best suited to carry out a service that can be delivered independently of whether it is going to be delivered a second time. Accordingly, different actors cannot fully substitute for one another and there is no longer a zero-sum game. Generous welfare state service provision will not replace services from other actors, but rather allow them to specialize in other forms of support (Daatland and Herlofsson 200r).

Although Litwak (1985) has included various kinds of welfare suppliers (such as voluntary organizations) in his complementarity theory, this theory has rarely been tested on the relationship between the welfare state and voluntary organizations. Instead, Litwak and a number of other researchers (for example Lingsom 1997; Lyons et al. 2000; Sundström et al. 2002) have studied the welfare state-family relationship. Then there is an alternative version of complementarity theory called "family support theory" (Lingsom I997; Daatland and Herlofsson 200I). However, this version has been specifically developed for the relationship between the state and the family, and is not applicable to the study presented in this article.

\section{Premises of the theories}

So, on what grounds can the theories discussed in this article be supported or questioned? Table I summarizes the roles of voluntary organizations in relation to the state, the tasks of voluntary and statutory organizations, and the predicted effects of increased statutory service provision on voluntary activity according to the theories of substitution, complementarity and welfare pluralism.

As mentioned above, the welfare pluralism approach to the provision of welfare services is not particularly well developed as a theory. So far, it has rarely, if ever, been clarified which testable premises would characterize welfare pluralism. Here, an attempt is made to operationalize welfare pluralism and test its premises. Welfare pluralism implies that similar kinds of services are offered by different actors, that is, that voluntary and statutory services can be seen as alternatives. This approach would thus be supported if there are overlaps between service provision by voluntary organizations and local authorities. These overlaps have to be found at a local level; that is, there must be a positive correlation between individual voluntary and statutory services.

To support the position of substitution (see Lingsom 1997) it is necessary to show that states or municipalities with extended statutory activities have limited voluntary activities. Longitudinally, an increase in the activity of one actor should lead to a decrease in the total activity of another actor. Similarly, a decrease in care from one actor should lead to replacement of this care by 
Table I

Roles, activity and predicted effects of increased statutory service provision according to a welfare pluralism approach, substitution theory, and complementarity theory

\begin{tabular}{|c|c|c|c|c|c|}
\hline & $\begin{array}{l}\text { Roles of voluntary } \\
\text { organizations in }\end{array}$ & $\begin{array}{l}\text { Voluntary and } \\
\text { statutory activity }\end{array}$ & \multicolumn{2}{|c|}{$\begin{array}{l}\text { Predicted effects of increased } \\
\text { service provision by one actor }\end{array}$} & \multirow{2}{*}{$\begin{array}{l}\text { Correlation between } \\
\text { voluntary and } \\
\text { statutory services }\end{array}$} \\
\hline $\begin{array}{l}\text { Welfare pluralism } \\
\text { approach }\end{array}$ & Alternative & Similar & Duplication of services & $\begin{array}{l}\text { Implied increase } \\
\text { of activity }\end{array}$ & \\
\hline Substitution theory & Substitutive & Similar & $\begin{array}{l}\text { Less activity by the other } \\
\text { actor, i.e. crowding out }\end{array}$ & $\begin{array}{l}\text { Constant sum } \\
\text { of activity }\end{array}$ & Negative \\
\hline $\begin{array}{l}\text { Complementarity } \\
\text { theory }\end{array}$ & Complementary & Different & $\begin{array}{l}\text { Unaffected activity by } \\
\text { the other actor }\end{array}$ & $\begin{array}{l}\text { Increased sum } \\
\text { of activity }\end{array}$ & None \\
\hline
\end{tabular}


another actor. In other words, there is a negative relationship between activities from states/local authorities and voluntary organizations.

According to complementarity theory, an increase of one actor's activity will lead to an increase in the total sum of activities (see Lingsom I997). The amount of activity of the other actor is either increased or unaffected; the main argument is that the total amount of activity is increased. This means that there is neither a positive nor a negative correlation between voluntary and statutory activities. The theory also assumes that different actors specialize in different tasks, that is, that there is not a great overlap in what kind of services the actors carry out. This theory will thus be challenged if statutory and voluntary services are of similar kind.

\section{Methods}

In this article, interaction between voluntary and statutory services will be analysed both cross-sectionally and longitudinally. Thereby, this study considers whether activity by one actor influences activity by the other actor. The article is based on two questionnaire surveys of voluntary and statutory services to support carers of older people. The surveys were conducted in I999 and 2002, respectively. This article will mainly present the findings of the 2002 survey and the longitudinal analysis, whereas the findings of the I999 questionnaire have been presented elsewhere (Dahlberg 2004).

\section{Political arena and period}

One of the core areas of the Swedish, and most other, welfare systems is the care of older people. In the context of the current demographic development towards an increasing proportion of older people in the population (European Commission 2004), the future organization of old-age care is of great importance. In Sweden, local authorities are responsible for the welfare of their citizens, for instance seeing that older people and family carers receive the support they need.

Families and other relatives contribute a considerable amount to the care of older people. Although their contributions are difficult to estimate (for a discussion, see Szebehely I998), a seminal study finds that family carers of older people undertake about two-thirds of the care for older people living in the community in Sweden (Johansson I99I; see also Socialstyrelsen 2005). Research demonstrates that caring for an older relative can be both a positive and a negative experience (see e.g. Almberg I999; Grafström I994; Lundh and Nolan 200r). Due to the drawbacks and stressful effects of caring, many family carers need support.

This is an area of growing interest in Swedish social welfare, and has over recent years been subjected both to increased attention from researchers and to state-stimulated and -funded development. Since I998, the state by law (the Social Services Act) recommends local authorities to support and relieve relatives, and in the period I999-200 I the Swedish state invested SEK 300 million in the development of support for family carers - a subsidy called "Anhörig 300" (anhörig is the Swedish word for "relative"). The funding was 
obtained by local authorities only, but the state encouraged local authorities to collaborate with voluntary organizations in their development of services.

The surveys on which this article is based were carried out within the area of support for relatives of older people in Sweden during the period of spring I999 to spring 2002. Due to the state subsidy Anhörig 300, one could expect to find changes in the support system over this period. This offered a unique opportunity to examine the association between voluntary and statutory service provision and its development in a shorter period than otherwise required. A drawback of studying this period might be, though, that there were also cutbacks in statutory care for older people. These cutbacks might have increased the pressure on relatives (see e.g. Hägred et al. 2004) with consequences in terms of their greater need of support. If so, this has implications for the results, in increasing the demands on support for relatives and thereby extending the room for different support providers.

\section{Data collection}

The surveys covered a sample of 67 Swedish municipalities and I3 parts of larger municipalities, i.e. a total of 80 geographical entities (hereafter called "municipalities"). These were included in the study by a stratified representative selection ensuring that generalizations could be made from the sample for Sweden as a whole (for further details on the selection process, see Dahlberg 2003, 2004).

In each municipality the following voluntary organizations were surveyed: two nationwide organizations for pensioners (Pensionärernas Riksorganisation and Sveriges Pensionärsförbund), the Red Cross, parishes within the Swedish Church, the Dementia Association (Demensförbundet; a nationwide organization for relatives of people with dementia), and local organizations for carers affiliated to the Council for Carers in Sweden (Anhörigrådet i Sverige). In 1999, questionnaires were sent to $35^{8}$ voluntary organizations and the response rate was 72 per cent $(n=258)$. In 2002, a few newly started organizations were added, and the survey covered 365 organizations with a response rate of 82 per cent $(n=298)$. Moreover, 80 local authorities were surveyed (i.e. one per region). The response rate was 89 per cent $(n=7 \mathrm{I})$ in I999 and 83 per cent $(n=66)$ in 2002. Private companies are not common in the area of support for relatives in Sweden. In this study, services provided by companies are only indirectly included - the local authorities were asked to include all services they funded, no matter whether they were delivered by the authorities themselves or by private companies.

The questionnaires were developed on the basis of experiences drawn from similar studies conducted in I996 and 1997 (Dahlberg I996, I998), and a pilot study in 1999. Since local authorities and voluntary organizations in Sweden work under different conditions (for instance, voluntary organizations usually do not run institutions), the questionnaires to the two groups were not identical. In total, voluntary organizations were asked about I I different kinds of support activities and the local authorities about I7 (see Appendix).

Relationships between different variables were analysed by use of correlation analysis. Pearson product moment correlation was used for normally 
distributed interval data, while Spearman's rho correlation was used when the data were ordinal or not normally distributed. For within-subjects (i.e. repeated measures) analyses of dichotomous variables, the McNemar test was used, while for within-subject analyses of non-parametric data involving two groups, the Wilcoxon test was used (Bryman and Cramer 1994). Not all voluntary organizations and local authorities in the sample responded to both surveys. The measures of paired data are thus imperfect, since they only include voluntary organizations and local authorities answering both in 1999 and $2002\left(n=223\right.$ voluntary organizations, and $n=5^{8}$ local authorities).

\section{Results}

\section{Levels of support}

In 2002, some 137 of 298 voluntary organizations stated that they were involved in support for relatives, i.e. 46 per cent. In comparison, 9I of 258 organizations, i.e. 35 per cent, were doing so in 1999 (Dahlberg 2004). Thus, between 1999 and 2002 there was an increase in both numbers and proportions of voluntary organizations supporting relatives of older people $(p=0.005)$.

While it is optional for voluntary organizations to arrange welfare services and to support relatives, Swedish local authorities are responsible for the welfare of their citizens and they are also by law recommended to support relatives. In both 1999 and 2002, all the local authorities in the study offered support for relatives.

In 2002, the median number of support activities offered was o for voluntary organizations (see table 2), although among those 137 organizations that were at all active in supporting relatives of older people the median number of activities was 3. In total, a median of 4 activities was offered by voluntary organizations in each municipality. There was a tendency for the number of voluntary activities per municipality to increase compared with the situation in $1999(t=-2.372 ; p=0.018)$.

The median number of support activities arranged by local authorities was Io, which was an increase since $1999(t=-5 . \mathrm{I} 64 ; p<0.00 \mathrm{I})$. The median of the sum of voluntary and local authority activities per municipality was 15 , which also was an increase since I999 $(t=-4.666 ; p<$ o.ooI $)$.

It is important to note that the amount of support activities varied substantially across the municipalities. In several municipalities no voluntary activities at all were arranged. In 2002, at the most i9 voluntary activities were arranged within one municipality. Two local authorities offered only 4 kinds of support, whereas one offered I6. The total sum of activities arranged by voluntary organizations and local authorities in each municipality varied between 5 and 30 .

\section{Overlapping areas of support}

So, was this service provision complementary? Did the actors substitute for one another, or did they contribute to a welfare pluralism? While details on what different kinds of services were provided by voluntary organizations and 
Number of support activities provided by voluntary organizations and local authorities in 2002

\begin{tabular}{|c|c|c|c|}
\hline & Median & Range & $\mathcal{N}$ \\
\hline Voluntary organizations & 0.0 & o, Iо & 298 \\
\hline "Active" voluntary organizations ${ }^{\mathrm{a}}$ & 3.0 & o, Iо & I37 \\
\hline Voluntary activity per municipality & 4.0 & o, I9 & 80 \\
\hline Local authorities & I0.0 & $4, \mathrm{I} 6$ & 66 \\
\hline Voluntary and statutory activity per municipality & I5.O & 5,30 & 66 \\
\hline
\end{tabular}

a“"Active" voluntary organizations means organizations that have said that they do see support for relatives as part of the organization's activity. Not all of these organizations were themselves arranging support activities. Other ways of being engaged in the issue are, for example, by cooperating with local authorities in the planning of activities, or being part of the opinionmaking process.

local authorities have been presented elsewhere (Dahlberg 2003; cf. Jegermalm 2003), here focus is placed on whether there were any overlaps of support provision. Whereas both substitution theory and the welfare pluralism approach imply that voluntary organizations and local authorities provide the same kind of services, overlaps between their services would question complementary theory.

There were several areas of support where both voluntary organizations and local authorities were active. The most substantial overlaps of voluntary and statutory service were found in the areas of group support, education and information. Both voluntary organizations and local authorities arranged study circles, support groups and lectures on a regular basis. These were key areas for voluntary organizations, at the same time as some of the greatest increases of local authority support between 1999 and 2002 took place here.

There were also some overlaps in terms of both care sitter services and day care centres. A few voluntary organizations provided care sitter services within their befriending services, and local authorities provided this within their home help service. A lot of the voluntary organizations arranged meeting points or day centres, and most of the local authorities provided support to relatives through day care.

Another overlap in activity was found regarding individual, advisory support for relatives, although the extent of this overlap is difficult to judge. While many local authorities provided this support, the study cannot make any firm statements about how common individual, advisory support by voluntary organizations was, since this was only indirectly measured. The study shows, though, that some parishes gave substantial individual, advisory support. However, these overlaps should not be overestimated. Statutory care sitter services were usually frequent and provided on a regular basis, whereas voluntary care sitter services were often more ad hoc. Voluntary meeting 
points or day centres were in general places for relatives to meet other relatives, but rarely included a care sitter service and, if so, usually not for more than a few hours. Statutory day care centres, on the other hand, always relieved carers by offering them the opportunity to leave their older relatives there on a regular basis. The statutory day care centres also often included rehabilitation for the older person. On top of this, most local authorities ran extended respite care, and many of them also provided night care services.

Nevertheless, this study has identified several overlapping areas of service provision, and these are contradictory to the assumptions of complementarity theory, which states that the actors should specialize in different activities. Instead, the increase in support levels and the overlaps of activity suggest that there might have been a transition towards welfare pluralism. However, before any definite conclusions can be drawn, the association between voluntary and statutory service provision must be reconsidered.

\section{Associations in 1999 and 2002}

The main test for the theories studied in this article is whether there was any association between the levels of voluntary and statutory service provision. Does substantial local authority activity, as assumed by substitution theory, crowd out voluntary activity? Or can the actors, on the contrary, support and stimulate one another?

A way of analysing the association of service provision is, as above, to measure how many different kinds of activities were arranged by voluntary organizations and local authorities within each municipality, and to examine the correlation between voluntary activity and local authority activity. When doing so, it has previously been shown that an extremely low correlation was found in I999 (Dahlberg 2004). In 2002, however, there was a positive association between voluntary and statutory activity. This means that in municipalities with a great amount of activities from one actor it was more likely that the other actor arranged a great amount of activity as well (see table 3 ). Since in many municipalities there were no voluntary activities arranged at all, it might be appropriate to exclude these municipalities from the analyses. As presented in table 3 , the correlation in only those municipalities where both voluntary and local authorities activity were arranged was, however, of similar magnitude.

As mentioned earlier, the questionnaires to local authorities and voluntary organizations were not identical. Because of this one could argue that the comparisons made so far are not an adequate test of substitution theory. However, in total seven identical questions were asked on support activities to both local authorities and voluntary organizations (specified in the first paragraph of the Appendix). A correlation analysis was carried out on a summary of these questions. Within this restricted range of activity, the correlations found for 2002 were still significant, when including (a) all municipalities and (b) just those in which both voluntary and local authority activity were arranged. These positive correlations strongly challenge substitution theory. No negative correlations were found in the I999 data either - then, no significant correlations were found (Dahlberg 2004). 
Correlations between activities arranged by voluntary organizations and local authorities in $2002(n=66)$

\begin{tabular}{lcc}
\hline & $r$ & $p$ \\
\hline $\begin{array}{l}\text { Correlation between local authority and voluntary activity } \\
\begin{array}{l}\text { Correlation between local authority and voluntary activity } \\
\text { in only those municipalities where both voluntary and local } \\
\text { authority activity were arranged }\end{array}\end{array}$ & 0.317 & 0.010 \\
$\begin{array}{l}\text { Correlation between local authority and voluntary activity } \\
\quad \text { common to both local authorities and voluntary organizations }\end{array}$ & $0.34^{\mathrm{a}}$ & 0.019 \\
$\begin{array}{l}\text { Correlation between local authority and voluntary activity } \\
\quad \text { common to both in only those municipalities where both } \\
\text { voluntary and local authority activity were arranged }\end{array}$ & 0.004 \\
$\begin{array}{l}\text { Correlation between local authority and voluntary activity } \\
\text { for relatives of older people living in the community }\end{array}$ & $0.33^{2}$ & 0.020 \\
$\begin{array}{l}\text { Correlation between local authority and voluntary activity } \\
\text { for relatives of residential-based older people }\end{array}$ & $0.133^{\mathrm{b}}$ & 0.288 \\
\hline
\end{tabular}

${ }^{a}$ These activities are specified in the first paragraph of the Appendix.

${ }^{\mathrm{b}}$ Spearman's rank order correlation was used for these tests.

Another possibility is that voluntary organizations and local authorities would substitute one another by supporting different groups of relatives, i.e. relatives of community-based and residential-based older people, respectively. This possibility was studied within the activities common to voluntary organizations and local authorities, but no supportive evidence was found (see table 3).

Although the analyses so far have not found any negative correlation between voluntary and statutory activity, substitution theory cannot yet be ruled out. It is still possible that substitution might work within individual forms of activity at a local level. For example, support groups arranged by the local authority might be correlated with support groups arranged by voluntary organizations - where a negative correlation would indicate that the actors substitute one another, while a positive correlation would indicate welfare pluralism. Therefore, correlation analyses were carried out, within each form of support activity arranged by both local authorities and voluntary organizations. A positive correlation was found between voluntary and statutory arranged lectures for relatives of older people living in the community in $2002\left(r_{s}=0.252 ; p=0.04 \mathrm{I}\right)$. Apart from this, no further significant correlations were found $\left(r_{s}=-0.057\right.$ to $r_{s}=0.22 \mathrm{I}$, for all $\left.p>0.05\right)$. Similar results have been found regarding the situation in I999 (Dahlberg 2004). This means that there was no general pattern of the same kind of service being arranged by both actors at a local level.

In other words, these analyses give no support to substitution theory. There are no indications that extensive statutory services would crowd out 
voluntary service, or vice versa. Neither do the findings support welfare pluralism. Hardly any correlations between individual voluntary and statutory support activities were found. Even though there are positive correlations between voluntary and statutory activity at an aggregated level, users rarely have the potential to choose between different service providers locally.

\section{Changes over time}

All the tests of association between voluntary and statutory activity made so far have been carried out in 1999 and 2002 separately. In the defence of substitution theory, one could argue that, although these tests contribute to the understanding of the relationship, they are limited in being just snapshots of a changing situation. Therefore, longitudinal analyses of the association were conducted in order to answer the crucial question of whether an increase in services from one actor leads to a decrease in services from the other actor.

Between 1999 and 2002 some of the voluntary organizations greatly extended their activities to support relatives of older people, while others decreased their provision of support (see table 4). Taken together, the increases equal the decreases and there was no change in the mean number of voluntary activities - neither per voluntary organization nor per municipality. On the other hand, there was an extension of support for relatives by local authorities. The mean increase was 2.7 activities per local authority.

So, does an increase in activity provided by one actor lead to a decrease in activity from the other actor? When studying the association between the change scores of voluntary and statutory activity, no significant correlations were found - neither when all the activities were included in the analysis $(r=-0.022 ; p=0.872)$ nor when only those activities common to both actors (specified in the first paragraph of the Appendix) were included $(r=0.072 ; p$ $=0.589$ ).

It is possible, though, that an increase in one activity by one actor might not affect a completely different activity by the other actor. Therefore, the association was studied within each specific form of support activity common to both actors. Even when this was done, no significant correlation was found

\section{Table 4}

Change in numbers of activities arranged by voluntary organizations and local authorities between 1999 and 2002

\begin{tabular}{lcccr}
\hline & Mean & Median & Range & $\mathcal{N}$ \\
\hline Voluntary organizations & +0.2 & 0 & - II,+8 & 223 \\
Voluntary activity per municipality & +0.4 & 0 & - II,+ I2 & 80 \\
Local authorities & +2.7 & +2.5 & $-4,+9$ & 58 \\
Voluntary and statutory activity per municipality & +3.9 & +3.5 & - I2, + 17 & 58 \\
\hline
\end{tabular}


between the change of voluntary and statutory activity in respect of any of the support activities (the range of correlation coefficients was $r=-0.225$ to $r=0.255$, for all $p>0.05$ ). Consequently, substitution theory is once again challenged.

\section{Discussion}

Several theories have been developed around the relationship between voluntary and statutory organizations as service providers. These theories have different origins and are based on different assumptions, and one might ask how these theories can contribute to an understanding of this relationship. In this article, the welfare pluralism approach, substitution theory and complementarity theory have been tested.

\section{The welfare pluralism approach}

The welfare pluralism approach is based on the assumption that voluntary organizations and local authorities are able to carry out similar tasks. The results of this study show that voluntary organizations and local authorities to some extent arranged similar kinds of services, such as study circles, support groups, and lectures in order to support relatives. In the period 1999-2002, the statutory support for relatives increased at the same time as a greater number of voluntary organizations became engaged in supporting them. Furthermore, a positive relationship was found between voluntary and statutory activities in 2002. At first sight, the welfare pluralism approach thus appears to correspond with the development of alternative services by voluntary organizations and local authorities shown in this study.

However, the fundamental assumptions of the welfare pluralism approach did not find any support. When examining individual support activities in 8o Swedish municipalities, hardly any positive correlations between voluntary and statutory activities were found. This means that even though many voluntary and statutory activities can be provided in the same municipality and even though these actors arrange the same kinds of activities, at a local level the voluntary and statutory activities tend to be of different kinds and users do not usually have the potential to choose between different service providers.

It could be argued that this study only captures a limited part of the "welfare market", since contributions from the family were not included in the study and contributions from private companies were only indirectly measured. The reason for not including family contributions is methodological. Considering that the measurement of family support to older people is linked with a range of methodological problems (for a discussion, see Szebehely I998), family support to relatives, i.e. other family members, is likely to be even more problematic to measure in a satisfying and reliable way. Although contributions of private organizations to the care of older people has grown over the last decade, the sector is still dominated by local authorities and it can be anticipated that the contributions of private organizations are even more limited in the secondary area of support for relatives. Therefore, 
no differentiation was made between their contributions and local authority contributions.

In any case, this study shows that by no means all services users are in a situation where a variety of alternatives are offered to them, even though the Swedish development since the early ig9os has previously been described as a "choice revolution" (Blomqvist 2004: I39). In other words, the welfare pluralism approach is not yet useful in describing interaction between variation of service provision from voluntary organizations and local authorities - at least not in this area and at least not if by "welfare pluralism" it is meant that users should be offered a choice between alternative service providers.

Still, in this area voluntary organizations are involved in service provision to a greater extent in 2002 than in I999. Parallel trends are apparent regarding care for older people in general, where private companies are now more established than a decade ago (Engström 2004; Trydegård 200I) as well as in other areas of the welfare state such as health care, child care, and primary education (Blomqvist 2004; Trydegård 200I). There has also been an ideological shift, which allows actors such as voluntary organizations and private companies to establish themselves in areas such as care for older people. In the long run, this might mean that most older people in need of care can choose between different providers of this care, although the welfare state is still playing the key role in service provision and can hardly be characterized as dying - as suggested in some of the debates referred to by way of introduction.

This means that the current transformation of the Swedish welfare state is of a "qualitative, rather than quantitative, nature" (Blomqvist 2004: I5I), where values such as social equality, universal rights and solidarity are gradually replaced by consumerism, individual rights, economic efficiency and private initiative. In that respect, this development can be seen as one step away from the traditional social democratic welfare regime with its strong emphasis on universalism, egalitarianism and solidarity (Esping-Anderson I990; Powell and Barrientos 2004; Sundström et al. 2002).

\section{Substitution theory}

Substitution theory implies that Sweden and other countries with large welfare states have very limited voluntary activity. This study found no significant negative correlation between voluntary and statutory services. Some municipalities with a great deal of local authority services also had considerable voluntary services, while some municipalities had limited statutory activity as well as limited voluntary activity. In 2002, there was even a positive correlation between voluntary and statutory activity; that is, in municipalities with extensive activity by one actor, extensive activity by the other actor was more likely. Nor was any evidence of crowding-out processes found in the longitudinal analysis. On the contrary, in many municipalities there was an increase of support for relatives by both the local authority and voluntary organizations in the period studied - with a greater sum of activities as an end result. 
Here, it is important to remember that this study was conducted in a period when the state made a major investment in stimulating the development of support for relatives. This investment made it unlikely that the sum of services would remain constant. On the other hand, in a situation with additional funding for the development of local authority services, substitution of voluntary services would have been likely. This study demonstrates that substitution did not occur even in this situation.

No evidence was found for an inverse relationship between voluntary and statutory activity, and the assumption that room for voluntary work is constrained in the social democratic regimes (Anheier and Salamon 200I) does not appear to hold true. Nothing indicated that there would be a zero-sum game between statutory and voluntary activity, and thus the fundamental assumptions of substitution theory found no support.

\section{Complementarity theory}

This article shows that there was not a complete specialization in services provided by voluntary organizations and local authorities. Voluntary organizations as well as local authorities arranged study circles, support groups, lectures, and to some extent individual, advisory services and relief services such as care sitter services and day care centres/meeting points. There was thus no clear-cut division between the kinds of services provided by voluntary organizations and local authorities.

Nevertheless, the overlaps in services provided by voluntary organizations and local authorities were found principally at an aggregated level. When studying individual support activities, no correlations were found; that is, voluntary organizations and local authorities rarely provided the same kind of services at a local level. In other words, although there was not a complete specialization in tasks carried out by voluntary organizations and local authorities, complementarity theory corresponds well with what is going on locally.

In addition, activities such as day care, care sitter services and extended respite care are extensive forms of support, and when making conclusions on the accuracy of complementarity theory, it has to be considered that the analysis of this article did not take the significance, time and resources of the different support activities into account. In the analyses of the association between voluntary and statutory services, the amount of services provided by voluntary organizations and local authorities was operationalized as the number of services/support activities. This means that services which are continuous and relatively expensive as well as covering many users are placed on a level with ad hoc and cheaper services to fewer users. The reason for this methodological limitation is that an earlier survey on support for relatives (Dahlberg I998) showed that it was difficult to collect reliable data on the extent of services. As a consequence, the amount of services had to be operationalized as the number of services, that is the existence and breadth of services supplied rather than the number of relatives supported or the cost of providing the services. If it had been possible to weigh the service activities in relation to their significance and the resources used to provide them, the activity of local authorities would have proved to be more dominant. Thus, 
in the Swedish welfare system - at least in this area of it - voluntary organizations appear to be complementary to local authorities.

Nevertheless, according to complementarity theory, complementarity works at a structural level. This study shows that there were overlaps in services, which suggests that the actors did not only carry out tasks that match their structure - as claimed by Litwak (I985). In contradiction to Litwak's assumption that voluntary organizations are not suitable for longterm undertakings, voluntary organizations frequently arranged continuous group support and some of them arranged care sitter services.

When taking all of this into consideration, there are some circumstances questioning complementarity theory, while others support it. The main reservation about this theory has to do with the overlap in services. These overlaps mean that there is not a complete specialization to match the characteristics of the actors, as assumed by the theory.

So, how can there be a complementarity between voluntary and statutory activity locally at the same time as the structural elements of complementarity theory are questioned? Is it possible that there is an ideological support for an ideal of complementarity? If people who are active in voluntary organizations and social policy at a local level agree with the idea of complementarity, it is likely that this would influence the motives of volunteers to carry out voluntary work and the will of civil servants to collaborate with voluntary organizations.

In other words, it is likely that the mechanisms behind local complementarity relate to norms and ideals rather than to characteristics of the actors. However, in order to say anything definite about this, the theory of complementarity would have to be combined with contextual approaches to the relationship between voluntary organizations and local authorities. Within the theories tested in this article, voluntary organizations are only seen as shaped by public policies (cf. Wijkström and Lundström 2002). This means that their own initiative is neglected, and they are not seen as proactive and having influence on public discourse and social realities (cf. Evers I993; Amnå I995). By utilizing contextual approaches, a more nuanced knowledge of the qualitative relationship between voluntary organizations and local authorities would be obtained and the varying local conditions in which this relationship is created and recreated would be highlighted.

\section{Conclusions}

This study gives hardly any support to substitution theory. Neither crosssectional nor longitudinal analyses found any evidence for substitution processes in service provision. As a consequence, it is questioned whether substitution theory is at all valuable in research on the voluntary-statutory relationship in this area. Substitution seems to be a myth, and the theory's only practical use is to serve as a rhetorical tool in critique of the welfare state.

At first sight, the welfare pluralism approach appears to correspond with the development of alternative services by voluntary organizations and local authorities shown in this study. In the period studied, there was an increase in support activities by both actors, which might suggest that there was a 
duplication of services and a development towards welfare pluralism. However, there was no support for the basic assumption of the welfare pluralism approach - there was no positive correlation between individual voluntary and statutory services. This means that even though voluntary organizations and local authorities provide similar kinds of support, they are rarely provided in the same municipalities. In other words, voluntary organizations and local authorities rarely provide alternative services, and usually users do not have the potential to choose between different service providers.

Complementarity theory was questioned to a degree, since there were overlaps in the provision of services by voluntary organizations and local authorities. These overlaps were found at an aggregated level, whereas voluntary organizations and local authorities rarely provided the same kind of services at a local level. Although there was not a complete specialization in tasks carried out by voluntary organizations and local authorities, these actors tended to be complementary in their local service provision. In order to achieve greater understanding of the processes behind this complementarity, it is recommended that the study of service provision be combined with contextual approaches that can fully take the actors' views and opinions into account.

\section{Appendix}

The questionnaires to voluntary organizations and local authorities were not identical. Given that voluntary organizations are not obliged to support relatives, they were asked if this issue was seen as part of their work. After that, both local authorities and voluntary organizations were asked questions on support activities for relatives of community-based and residential-based older people. Regarding support for family carers of older people in the community, they were asked about: (I) lectures, (2) support groups and study circles, (3) care sitter services (in the home of the older person), and (4) an open-ended question on other kinds of support. Regarding support for family carers of residential-based older people the questionnaires included questions on the provision of: (5) lectures, (6) support groups and study circles, and (7) an open-ended question on other kinds of support.

In addition, voluntary organizations were asked if they arranged: (I) a visitor service within befriending services, (2) an escort service within befriending services, (3) other services within befriending services, and (4) a meeting point or a day centre. Local authorities were also questioned regarding: (I) advisers for family carers, (2) dementia support nurses, (3) a person or office responsible for contacts with family carers who are employed by the local authority, (4) a person or office responsible for contacts with family carers other than those employed by the local authority, (5) respite care (in institutions), (6) day care, (7) night care, (8) invitations to carers to participate in staff training, (9) employment of carers, and (Io) financial support/subsidies.

\section{Acknowledgements}

This study was funded by the Swedish National Board of Health and Welfare together with i4 local authorities and the County Council in Dalarna. For 
valuable comments on drafts of this article, I am grateful to Kevin McKee, Sheffield Institute for Studies on Ageing, Sheffield University, and the two anonymous reviewers.

\section{References}

Almberg, B. (I999), Family caregivers caring for relatives with dementia: pre- and post-death experiences. PhD thesis, Karolinska Institutet.

Amnå, E. (I995), Det mångtydiga mellanrummet: några utländska forskningsimpulser [The ambiguous place between: some international research ideas]. In E. Amnå (ed.), Medmänsklighet att hyra [Human kindness for hire?], Örebro: Libris, pp. Iı7 I.

Andreoni, J. (1993), An experimental test of the public-goods crowding-out theory, American Economic Review, 83, 5: I3I7-27.

Anheier, H. K. and Salamon, L. M. (200I), Volunteering in a Cross-national Perspective: Initial Comparisons, London: Centre for Civil Society, London School of Economics and Political Science.

Barnes, M. and Walker, A. (I996), Consumerism versus empowerment: a principled approach to the involvement of older service users, Policy and Politics, 24, 4: 375-93.

Blennberger, E. (1993), Begrepp och modeller [Concepts and models]. In SOU I993:82, Frivilligt socialt arbete: Kartläggning och kunskapsöversikt [Voluntary social work: Mapping and research overview], Stockholm: Socialdepartementet, pp. 33-53.

Blomqvist, P. (2004), The choice revolution: privatization of Swedish welfare services in the I99os, Social Policy \& Administration, 38, 2: 139-55.

Boli, J. (I99I), Sweden: is there a viable third sector? In R. Wuthnow (ed.), Between States and Markets: The Voluntary Sector in Comparative Perspective, Princeton, NJ: Princeton University Press, pp. 94-I24.

Brunner, E. J. (I997), An empirical test of neutrality and the crowding-out hypothesis, Public Choice, 92, 3/4: 26r-79.

Bryman, A. and Cramer, D. (I994), Quantitative Data Analysis for Social Scientists, London and New York: Routledge.

Daatland, S. O. and Herlofsson, K. (200I), Service systems and family care: substitution and complementarity? In Daatland, S. O. and Herlofsson, K. (eds), Ageing, Intergenerational Relations, Care Systems and Quality of Life: An Introduction to the OASIS Project, Oslo: NOVA, pp. 53-6г.

Dahlberg, L. (1996), Dalarnas anhörigstöd: Kartläggning av stöd till anhöriga som vårdar äldre närstående i hemmet [Support for relatives in Dalarna: Mapping of support for relatives caring for older people in the community], Falun: Dalarnas forskningsråd.

Dahlberg, L. (I998), Stöd till äldres anhöriga: En nationell kartläggning [Support for relatives of older people: A national survey], Stockholm: Socialstyrelsen.

Dahlberg, L. (2003), Voluntary organizations in a strong welfare state: a study of support for relatives of older people in Sweden, Generations Review, I3, 4: 4-8.

Dahlberg, L. (2004), Substitution in statutory and voluntary support for relatives of older people, International Journal of Social Welfare, I3, 2: 18I-8.

Engström, B. (2004), Konkurrensutsättning och entreprenader inom äldreomsorgen: Utvecklingsläget 2003 [Competition and contractors within care for older people: Status report 2003], Stockholm: Socialstyrelsen.

Esping-Andersen, G. (I990), The Three Worlds of Welfare Capitalism, Cambridge: Polity Press.

Esping-Andersen, G. (I994), Jämlikhet, effektivitet och makt [Equality, efficiency and power]. In P. Thullberg and K. Östberg (eds), Den svenska modellen [The Swedish model], Lund: Studentlitteratur, pp. 75-Io6. 
Esping-Andersen, G. (2002), Towards the good society, once again? In G. EspingAndersen (ed.), Why We Need a New Welfare State, Oxford: Oxford University Press, pp. I-25.

European Commission (2004), The Social Situation in the European Union 2004. Available at: http://europa.eu.int/comm/employment_social/publications/2004/keago40oI_en. pdf (accessed io February 2005).

Evers, A. (I993), The welfare mix approach: understanding the pluralism of welfare systems. In A. Evers and I. Svetlik (eds), Balancing Pluralism: New Welfare Mixes in Care for the Elderly, Aldershot: Avebury, pp. 3-31.

Forder, J., Knapp, M. and Witow, G. (1996), Competition in the mixed economy of welfare, fournal of Social Policy, 25, 2: 201-2I.

Giddens, A. (1999), The Third Way: The Renewal of Social Democracy, London: Polity Press.

Graefe, P. (2004), Personal services in the post-industrial economy: adding nonprofits to the welfare mix, Social Policy \& Administration, 38, 5: 456-69.

Grafström, M. (I994), The experience of burden in the care of elderly persons with dementia. PhD thesis, Karolinska Institutet.

Hägred, U., Hedman, E., Johansson, L., Eriksson, T. and Flyckt, K. (2004), Varför kan inte behovet av särskilda boendeformer tillgodoses? [Why cannot the need for residential settings be met?], Stockholm: Boverket and Socialstyrelsen.

Hatch, S. and Mocroft, I. (I983), Components of Welfare. Voluntary Organizations, Social Services and Politics in Two Local Authorities, London: Bedford Square Press of the National Council for Voluntary Organizations.

Henriksen, L. S. (I996), Lokal frivillig organisering i nye omgivelser [Local voluntary organization in new surroundings]. PhD thesis, Aalborg Universitet.

James, E. (I989), The private provision of public services: a comparison of Sweden and Holland. In E. James (ed.), The Nonprofit Sector in International Perspective, Oxford: Oxford University Press, pp. $3^{\mathrm{I}-60}$.

Jegermalm, M. (2003), Support for carers of older people: the roles of the public and voluntary sectors in Sweden, Social Policy \& Administration, 37, 7: 756-71.

Johansson, L. (I99I), Caring for the next of kin: on informal care of the elderly in Sweden. PhD thesis, Uppsala Universitet.

Johansson, S. (200I), Självständiga rörelser eller kommunala underleverantörer? Ideella organisationers roll $i$ välfärdssystemet [Independent movements or statutory supplier? The role of voluntary organizations in the welfare system], Göteborg: CEFOS.

Johnson, N. (1987), The Welfare State in Transition: The Theory and Practice of Welfare Pluralism, Brighton: Wheatsheaf.

Johnson, N. (I990), Problems for the mixed economy of welfare. In A. Ware and R. Goodin (eds), Needs and Welfare, London: Sage, pp. I45-64.

Kjöller, H. (2002), Omsorgens dödgrävare [The gravedigger of care], Dagens Nyheter (9 August).

Kramer, R. M. (I992), The roles of voluntary social service organizations in four European states: policies and trends in England, the Netherlands, Italy and Norway. In S. Kuhnle and P. Selle (eds), Government and Voluntary Organizations: A Relational Perspective, Aldershot: Avebury, pp. $34^{-52}$.

Kuhnle, S. and Alestalo, M. (2000), Introduction: growth, adjustments and survival of European welfare states. In S. Kuhnle (ed.), Survival of the European Welfare State, London: Routledge, pp. 4-18.

Kuhnle, S. and Selle, P. (I992), Government and voluntary organizations: a relational perspective. In S. Kuhnle and P. Selle (eds), Government and Voluntary Organizations: A Relational Perspective, Aldershot: Avebury, pp. I-33.

Künemund, H. and Rein, M. (I999), There is more to receiving than needing: theoretical arguments and empirical explorations of crowding in and crowding out, Ageing and Society, I9: 93-12 I. 
Langan, M. (2000), Social services: managing the third way. In J. Clarke, S. Gewirtz and E. McLaughlin (eds), New Managerialism, New Welfare? London: Sage, pp. I5268.

Larsson, L. (2002), När EU kom till byn [EU in the village]. PhD thesis, Uppsala Universitet.

Lingsom, S. (1997), The substitution issue: care policies and their consequences for family care. PhD thesis, NOVA.

Litwak, E. (1985), Helping the Elderly: The Complementary Roles of Informal Networks and Formal Systems, New York: Guilford Press.

Lorentzen, H. (I998), Normative forståelser av sivile sammenslutninger [Normative understandings of civil associations], Socialvetenskaplig Tidskrift, 5, 2/3: 244-67.

Lundh, U. and Nolan, M. (200I), Närståendes vård av äldre: Anhörigas och professionellas perspektiv [Relatives' care of older people: Perspectives of relatives and professionals], Stockholm: Socialstyrelsen.

Lyons, K. S., Zarit, S. H. and Townsend, A. L. (2000), Families and formal service usage: stability and change in patterns of interface, Aging and Mental Health, 4, 3: $234-43$.

Montin, S. (I997), New Public Management på svenska [New public management in Swedish], Politica, 29, 3: 26I-78.

Pestoff, V. A. (I992), Third sector and co-operative services: an alternative to privatization, fournal of Consumer Policy, I5, I: 21-45.

Powell, M. and Barrientos, A. (2004), Welfare regimes and the welfare mix, European Journal of Political research, 48, I: 83-105.

Powell, M. and Hewitt, M. (I998), The end of the welfare state? Social Policy \& Administration, 32, I: I-I3.

Premfors, R. (I999), Den svenska modellen som demokrati [The Swedish model as democracy]. In E. Amnå (ed.), Demokrati och medborgarskap [Democracy and citizenship], Stockholm: Fritzes, pp. I35-6o.

Proposition 1997/98:113. Nationell handlingsplan för äldrepolitiken [The national plan for policy on older people].

Rothstein, B. (1998), Den svenska modellens uppgång och fall: en essä [The rise and fall of the Swedish model: an essay], Statsvetenskaplig Tidskrift, Ior, I: 4 I-9.

Rothstein, B. (2002), Sweden: social capital in the social democratic state. In R. D. Putnam (ed.), Democracies in Flux: The Evolution of Social Capital in Contemporary Society, New York: Oxford University Press, pp. 289-33I.

Selle, P. and Øymyr, B. (I995), Frivillig organisering og demokrati: Det frivillige organisasjonssamfundet 1940-I990 [Voluntary organization and democracy: The society of voluntary organization 1940-1990], Oslo: Det Norske Samlaget.

Socialstyrelsen (2003), Så ser vi det. Socialstyrelsens syn på och förhållande till den ideella sektorn [The way we see it. The Swedish National Board of Health and Welfare's view on and relationship to the voluntary sector], Stockholm: Socialstyrelsen.

Socialstyrelsen (2005), Vard och omsorg om äldre. 2004 [Health and social care of older people. 2004], Stockholm: Socialstyrelsen.

Södersten, B. (2002), Svenska modellen fungerar inte [The Swedish model does not work], Dagens Nyheter (24 July).

Steinberg, R. (I987), Voluntary donations and public expenditures in a federalist system, American Economic Review, 77, I: 24-36.

Stolle, D. and Rochon, T. R. (I999), The myth of American exceptionalism: a threenation comparison of associational membership and social capital. In J. W. van Deth, M. Maraffi, K. Newton and P. F. Whiteley (eds), Social Capital and European Democracy, London: Routledge, pp. I92-209.

Sundström, G., Johansson, L. and Hassing, L. B. (2002), The shifting balance of longterm care in Sweden, The Gerontologist, 42, 3: 350-5. 
Szebehely, M. (I998), Hustruns hjälp eller hemtjänstens? [Help from the wife or the home help service?]. In Äldreomsorgens vardag [Everyday life of care for older people], Stockholm: Socialvetenskapliga forskningsrådet, pp. 73-88.

Trydegård, G.-B. (200I), Välfärdstjänster till salu: privatisering och alternativa driftsformer under i990-talet [Welfare services for sale: privatization and alternative management forms in the I99os]. In M. Szebehely (ed.), Välfärdstjänster $i$ omvandling [Welfare services in transition], SOU 2001:51, Stockholm: Socialdepartementet, pp. 77-I39.

Vogel, J. (I999), The European "welfare mix". Institutional configuration and distributive outcome in Sweden and the European Union: a longitudinal and comparative perspective, Social Indicators Research, 48: 245-97.

Walker, A. (I989), Community care. In M. McCarthy (ed.), The New Politics of Welfare: An Agenda for the I9gos? Basingstoke: Macmillan, pp. 203-24.

Wijkström, F. and Lundström, T. (2002), Den ideella sektorn: Organisationerna $i$ det civila samhället [The voluntary sector: organizations in civil society], Stockholm: Sober Förlag.

Wollmann, H. (2004), Local government reforms in Great Britain, Sweden, Germany and France: between multi-function and single-purpose organizations, Local Government Studies, 30, 4: 639-65.

Zetterberg, H. L. (I995), Civila samhället, demokratin och välfärdsstaten [Civil society, democracy and the welfare state]. In L. Trägårdh (ed.), Civilt samhälle kontra offentlig sektor [Civil society versus the public sector], Stockholm: SNS Förlag, pp. $64-93$. 